\title{
Quasi-Judicial Bodies as Procedural Innovations: The World Bank Access to Information Appeals Procedure
}

\author{
Edouard Fromageau*
}

\section{Introduction}

After years of criticism toward its mode of operation, ${ }^{1}$ the World Bank is now engaged in a major and drastic institutional reform aimed at enhancing its transparency and accountability through access to information. In July 2010, the World Bank Access to Information Policy (the AI Policy) was launched as one initiative to provide better access to information for the public. $^{2}$ A "landmark disclosure policy"3 for the World Bank, a "welcome step" ${ }^{4}$ or a "clear sign of the development of procedural norms that apply to global institutions" 5 for others, the AI Policy is nonetheless a major reform of the Bank's disclosure policy as it represents a "paradigm shift in the Bank's approach to disclosure". ${ }^{6}$ It has indeed redefined the way the

* Senior Research Fellow at the Max Planck Institute Luxembourg for Procedural Law.

1 See for example the long-standing criticism from the Global Transparency Initiative. B. Jenkins, The World Bank's New Access to Information Policy: Conceptual Leap with Limits, Bank Information Center - IFI Info Brief, (March 2010), 3 [Jenkins, The World Bank's New Access to Information Policy].

2 Another initiative is the Open Data Initiative, also launched in 2010, which allows access to World Bank data, including databases, pre-formatted tables, reports, and other resources. For more information on the Open Data Initiative, see http://data. worldbank.org (last visited 6 December 2018).

3 See Website of the World Bank, 'Access to Information', available at http://www.worldbank.org/en/access-to-information (last visited 6 December 2018).

4 B. S. Chimni, International Financial Institutions and International Law: A Third World Perspective, in D. D. Bradlow \& D. B. Hunter (eds.), International Financial Institutions and International Law (2010), 60.

5 M. Macchia, The rule of law and transparency in the global space, in S. Cassese (ed.), Research Handbook on Global Administrative Law (2016), 271.

6 World Bank, 'Toward Greater Transparency: Rethinking The World Bank's Disclosure Policy - Approach Paper', (January 2009), available at http://siteresources.worl dbank.org/INFODISCLOSURE/Resources/5033530-1236640024078/English_full.p df (last visited 6 December 2018), 2 [World Bank, Toward Greater Transparency]. 
Bank makes information accessible to the public by reversing the logic adopted for access to information; going from a policy which listed the information allowed to be made available, to the current approach of making available all the information in the Bank's possession as long as it is not on the list of exceptions. ${ }^{7}$ It has also established the Access to Information Appeals Procedure (the AI Procedure), a quasi-judicial two-stage process to hear appeals from decisions denying access to information. After a closer look at the AI Policy (I), this chapter will focus on the structure (II) and nature (III) of the AI Procedure. The novelty of this procedure will then be highlighted in the concluding remarks (IV).

\section{A Closer Look at the AI Policy}

The first efforts of the World Bank to enhance access to information began in 1985 with the adoption of the Directive on Disclosure of Information, which was the first instruction to staff on information disclosure. ${ }^{8}$ It established a "presumption in favour of disclosure" in the absence of compelling reasons not to disclose. The first formal disclosure policy was adopted in $1993^{9}$ where it has since been periodically reviewed and its scope has progressively expanded. Updates occurred in 2001 and 2005, with the adoption of proposals to allow access to additional documents. ${ }^{10}$ The pre-2010 policy was, then, a fairly wide-reaching policy listing all the categories of information that the Bank could disclose, the so-called "positive list".

Motivated by the criticisms mentioned above, but also by "a sense within the Bank that its own protocols fell short of what is urged on client countries" ${ }^{11}$ the Bank began the redrafting, in March 2009, of the policy with the release of an approach paper acknowledging that "the time has

7 World Bank, 'Access to Information Staff Handbook', June 2010, available at https: //policies.worldbank.org/sites/ppf3/PPFDocuments/090224b0823713bb.pdf (last visited 6 December 2018) 2.

8 See Website of the World Bank, 'Access to Information - timeline', available at http://www.worldbank.org/en/access-to-information/overview\#3 (last visited 6 December 2018).

9 World Bank, supra note $6,1$.

10 Ibid.

11 B. Kingsbury, Global Administrative Law in the Institutional Practice of Global Regulatory Governance, in H. Cissé et al. (eds.), The World Bank Legal Review Volume 3: International Financial Institutions and Global Legal Governance (2012), 20. 
come to take a fresh look at the Bank's disclosure policy framework"12 The approach paper highlighted various policy limitations such as, for example, the fact that a presumption against the disclosure of information was involuntarily created for documents not listed in the positive list, or that there was a lack of clarity on what is not to be disclosed. ${ }^{13}$

Several rounds of consultations with stakeholders then took place in 33 countries over three months in 2009; a consultation process that was admittedly "more extensive than what is typically seen at the World Bank".14 During the consultation meeting of April 2009 in Washington D.C, several participants urged the Bank to recognise the right of access to information as a fundamental human right. ${ }^{15}$ Bank officials ultimately declined, but affirmed that they understood the Bank is a "public body" 16 and as such it must have a compelling reason not to disclose information.

A revised draft of the disclosure policy was then released publicly by the Bank in October 2009, taking into account the results of the several rounds of consultation. ${ }^{17}$ The final version of the draft was adopted by the board of executive directors in November 2009. ${ }^{18}$ It is based on five guiding principles which require the Bank to maximize access to information, set out a clear list of exceptions, safeguard the deliberative process, provide clear procedures for making information available and, to recognize the requesters' right to an appeals process. ${ }^{19}$

12 World Bank, supra note 6, 2. This paper was the result of an approach discussed in December 2008 during a meeting between two Committees of the World Bank, the Committee on Development Effectiveness and the Committee on Governance and Executive Directors' Administrative Matters. See World Bank, Toward Greater Transparency - Rethinking the Bank's Disclosure Policy (December 2008).

13 Ibid.

14 D. B. Hunter, International Law and Public Participation in Policy-Making at the International Financial Institutions, in D. D. Bradlow \& D. B. Hunter (eds.), International Financial Institutions and International Law (2010), 223.

15 World Bank, Toward Greater Transparency: Rethinking The World Bank's Disclosure Policy - Summary of the Consultation Meeting, (April 2009), 1 [World Bank, Summary of Consultation Meeting 2009].

16 Ibid., 3.

17 World Bank, Toward Greater Transparency Through Access to Information - The World Bank's Disclosure Policy (Revised Draft) (October 2009), 1 [World Bank, Toward Greater Transparency - Revised Draft].

18 The AI Policy was, since then, revised on two occasions to refine its scope and to improve access to Bank information.

19 World Bank, 'Policy on Access to Information' (July 2015), available at http://pub docs.worldbank.org/en/393051435850102801/World-Bank-Policy-on-Access-to-Inf 
The AI Policy explicitly set out a list of the ten groups of documents which are considered to be exceptions. ${ }^{20}$ They concern the personal information of staff members (e.g. medical information, selection processes...); communications of governors and/or executive directors' offices; proceedings of the ethics committee for board officials; information subject to attorney-client privilege; security and safety information; information restricted under rules of other Bank entities; confidential member country and third-party information; corporate administrative matters (e.g. corporate expenses, real estate procurement...); deliberative information (e.g. official e-mails relating to Bank business...); and financial information (e.g. estimates of future borrowing, donor information...). These exceptions have been voluntarily drawn narrowly so as to protect legitimate and welldefined interests from potential harm. ${ }^{21}$ The AI Policy, however, allows for a "public interest override" by which management may decide to disclose restricted information "if it determines that the overall benefits of such disclosure outweigh the potential harm to" 22 protected interests. Similarly, the World Bank would reserve the right not to disclose, under exceptional circumstances, information that it would normally disclose, if it determines that such disclosure is likely to "cause harm that outweighs the benefits of disclosure". 23

\section{The Structure of the AI Procedure: a Two-Stage Appeals Process}

Unlike previous disclosure policies of the World Bank, the AI Policy provides for a procedure allowing requesters who are denied access to information by the Bank to file for an appeal. The idea to include such mechanism in the new AI Policy came from the Bank who recognized in the 2009 approach paper that the lack of an appeals process was one of the lim-

ormation-V2.pdf (last visited 6 December 2018), Section III, A. 1., 9 [World Bank, Policy on Access to Information].

20 Ibid., Section III, B. 2. 9.

21 It has been noted, however, that "several of the 10 listed exceptions are so broadly drafted that they may lead to the withholding of large volumes of uncontroversial information”. Jenkins, The World Bank's New Access to Information Policy, supra note 1,9 .

22 World Bank, supra note 19, Section IV, 1., 19.

23 Ibid., Section IV, 2., 20. 
itations of previous policies. ${ }^{24}$ The Bank stressed the need for a "disclosure policy-specific administrative appeals mechanism for those who wish to appeal disclosure decisions".25

The initial idea was however to create a single-stage five-member appeal panel headed by Bank senior management officials. ${ }^{26}$ The Bank also suggested that outside parties could be included, taking as an example the composition of its Sanctions Board. ${ }^{27}$ Since 2004, the Sanctions Board has been composed of seven members, three internal and four external members. Additionally, since 2009, the chair of the Sanctions Board must be selected from its external members. ${ }^{28}$ Originally, the Sanctions Board was composed entirely of members from the World Bank. ${ }^{29}$ This choice was justified at that time by the fact that members of the Bank were those who, on the basis of their knowledge and experience, were able to assess whether it was in the interests of the World Bank to continue to work with a company or an individual about whom there existed concerns of corruption or fraud. The modification of the Sanctions Board to include outside parties was based on the recommendations of the Thornburgh Report, an external panel in charge of reviewing the World Bank sanctions process. ${ }^{30}$ Invoking the "progressive solidification of the Bank's resolve to develop and demonstrate procedure in all of its operation that exemplify its commitment to fairness and due process" ${ }^{31}$ the panel suggested to change the composition to one of a mixed type with members both from the Bank and from outside of it. It is then most probably from this experience, and ultimately to prevent possible conflicts of interest and ensure that the so-

24 "The Bank does not have a clear mechanism to receive and respond to appeals about information to which access has been denied. The policy does not provide any guidance on whether there is a place/person within the Bank's management hierarchy to which requesters can appeal the initial disclosure decision if they feel that access to information has been unreasonably denied". World Bank, supra note 6,5 .

25 Ibid., 6-7.

26 Ibid.

27 Ibid.,13.

28 For more details, see L. Boisson de Chazournes \& E. Fromageau, Balancing the Scales: The World Bank Sanctions Process and Access to Remedies, 23(4) The European Journal of International Law (2012), 977-979.

29 Ibid., 977. In 2016, the World Bank started a transition to an all-external Sanction Board membership.

30 D. Thornburgh et al., 'Report Concerning the Debarment Processes of the World Bank' (2002), available at http://siteresources.worldbank.org/INTDOII/Resources/ thornburghreport.pdf (last visited 6 December 2018), 1.

31 Ibid., 21. 
called appeals panel acts in an independent and impartial manner, that the Bank suggested the possibility to include outside parties.

The proposal to create such an appeals panel was welcomed by stakeholders during the consultation rounds in 2009. Some stakeholders even saw such proposal as placing the Bank "at the cutting-edge of international financial institutions".32 Several concerns were highlighted during these rounds. It was important that the panel respond promptly to an appeal, ideally within 30 days. ${ }^{33}$ The question of the composition of the appeals panel was also a concern. ${ }^{34}$ The NGO Global Transparency Initiative (GTI) openly criticised the approach adopted by the Bank, noting that:

[Such body] falls short of [...] the call in the GTI Charter for a truly independent appeals mechanism. Why would this body be chaired by a Managing Director or include Regional Vice Presidents, as this would likely raise potential conflicts of interest? We call for the creation of an appeals body independent from operational management. At a minimum, we support the idea of including outside parties on the panel. ${ }^{35}$

The position of Bank officials during this round was to ensure that the proposed panel would include external parties to guarantee that "its decisions are independent of the Bank's management" ${ }^{36}$

The appeals process established by the AI Policy is, however, quite different. The first stage of the appeal process ${ }^{37}$ is conducted by the Access to Information Committee (AI Committee), a nine-member internal "admin-

32 World Bank, supra note 15, 2.

33 Ibid.

34 See, for example, E. Hanson, 'Ghana: Concerns Raised Over World Bank's New Disclosure Policy, TWN Africa Blog (June 2009), available at http://apps.twnafrica .org/Blog/?e=30336\&d=06/05/2009\&s=Ghana\%3A Concerns Raised Over World Bank\%27s New Disclosure Policy (last visited 6 December 2018).

35 B. Jenkins, "Brief Comments on World Bank 'Approach Paper”, GTI World Bank Transparency Review Update 3, (April 2009) 4.

36 World Bank, supra note $15,4$.

37 The AI Committee is also in charge of reporting to Bank management and advising management on the application of the AI Policy to complex issues, reviewing proposals to disclose information that is on the list of exceptions, establishing service fees and service standards, and issuing guidelines to staff on policy implementation. World Bank, supra note 15, Section III, 7. 19. 
istrative body" 38 composed fully of Bank staff members. ${ }^{39}$ Outside parties are to be found at the second stage of the process, in an "independent" 40 Appeals Board (AI Appeals Board) of three outside experts. ${ }^{41}$

This configuration was proposed to the Board of Executive Directors in the revised draft of the policy released by the Bank in October 2009, a document made available to the public after the several rounds of consultations. ${ }^{42}$ It was during these rounds that the idea of creating a two-stage appeals process was introduced. It was first suggested to the Bank to confer the "additional function of providing expedited, independent reviews of refusals to disclose information" ${ }^{43}$ to the World Bank Inspection Panel. ${ }^{44}$ The Bank declined and instead created a second-stage body of similar function to the Inspection Panel, also being composed of three independent external members. ${ }^{45}$

Another difference between the model suggested during the consultation rounds and the model adopted by the Bank concerns the jurisdiction of the second-stage body. The AI policy has indeed set out two distinct grounds for appeal: 1) if the requester establishes a prima facie case that the Bank has failed to disclose information which is not restricted and 2) if the

38 Ibid., Section III, 7. 18.

39 It consists of principal members and their alternates, representing the Operations Policy and Country Services (OPCS), External Affairs (EXT), Legal (LEG), Corporate Secretary Vice Presidency (SEC), General Services Department (GSD), Information Management and Technology (IMT) and one region.

40 World Bank, supra note 15, Section III, 8., (b), ii, 19.

41 See World Bank, 'AI Appeals Board', available at http://www.worldbank.org/en/access-to-information/ai-appealsboard (last visited 6 December 2018).

42 World Bank, supra note 17, 5: "The Bank recognizes requesters' right to an appeals process if they believe that the Bank has unreasonably denied access to information that should be publicly available under its Disclosure Policy. It would propose to adopt a two-stage appeals process: an internal panel and an independent panel. This process would include clear standards for the time for considering appeals". (emphasis added).

43 GTI, 'Model World Bank Policy on Disclosure of Information' (2009), available at http://www.ifitransparency.org/uploads/7f12423bd48c10f788a1abf37ccfae2b/GTI _WB_Model_Policy_final.pdf (last visited 6 December 2018), 3.

44 It was indeed suggested in the Washington D.C. round to use the World Bank Inspection Panel as an appeal body, "thereby avoiding the creation and expense of a new entity”. World Bank, supra note 15, 2.

45 Whereas the members of the Inspection Panel are appointed by the Board of Directors for a five-year non-renewable term, the members of the AI Appeals Board are nominated by the President, and endorsed by the Board of Executive Directors, for a two-year renewable period. 
appellant wishes to make a public interest case for disclosure to override the exceptions (the above-mentioned public interest override). ${ }^{46}$ These two grounds of appeal can be invoked before the AI Committee at the first stage of the appeal process. ${ }^{47}$ However, for appeals asserting a public interest override, the decision of the AI Committee is final. Denial of a request for a public interest override by the AI Committee cannot be brought before the AI Appeals Board. ${ }^{48}$ The latter's jurisdiction is then restricted to denial by the AI Committee on appeals asserting prima facie violations of the Policy. ${ }^{49}$

Such limitation of competence is likely motivated by the willingness of the World Bank to retain control over the information to be released on grounds of public interest. ${ }^{50} \mathrm{~A}$ sign of such motivation can be found in the revised draft of the Policy released in October 2009, where the Bank's officials invoked as a justification for the limitation that the "override is only to be exercised at the discretion of the Bank".51 Preventing external members from assessing public interest cases is clearly a flaw in the procedure. ${ }^{52}$ An assessment of a public interest case, indeed, calls for the inclusion of external members in the decision-making, as "internal bodies lack an objective view".53

46 World Bank, supra note 17, 15.

47 World Bank, supra note 19, Section III, 8, (b), i., 18.

48 Ibid.

49 Ibid.

50 A public interest override which is ab initio limited, as it only concerns three of the ten exceptions (corporate administrative matter, deliberative information and financial information).

51 World Bank, supra note 17, 16, para. 27.

52 In their comments on the revised draft, GTI "applauds the proposal in the draft Policy to create an independent appeals mechanism. It would be preferable to set out in more detail in the policy how the members are to be appointed and how the body is to function in practice. Furthermore, it should have wider powers, for example, to decide on public interest disclosures and to make general recommendations for reform or improvement”. GTI, 'Comments on Toward Greater Transparency Through Access to information: The World Bank's Disclosure Policy: Revised Draft' (2009) available at http://www.ifitransparency.org/uploads/7f12423bd 48c10f788a1abf37ccfae2b/GTI_comments_WBdisclosure_Nov 09.final.pdf (last visited 6 December 2018).

53 S. Fujita, The World Bank, Asian Development Bank and Human Rights - Developing Standards of Transparency, Participation and Accountability (2013), 132 [Fujita, The World Bank, Asian Development Bank and Human Rights]. 
As of November 2018, the AI Committee rendered 67 decisions on appeal. ${ }^{54}$ In 43 of those decisions (64\%), the AI Committee upheld the Bank's initial decision to deny access. 17 other cases (25\%) were dismissed because of inter alia an appeal on a matter that the AI Committee did not have authority to consider, or an untimely filing of appeal. ${ }^{55}$ In only 7 cases $(11 \%)$ did the AI Committee reverse the decision of the Bank and allow access to the documents. 6 of these cases were on the basis of a prima facie violation, the remaining case was one of public interest. With respect to the grounds of appeal, a prima facie violation was argued in 18 cases (27\%), a public interest override was requested in 15 cases (22\%), and in 34 cases both grounds were invoked (51\%). Meanwhile, 10 decisions were rendered by the AI Appeals Board, ${ }^{56}$ upholding the denial of the AI Committee in 6 cases $(60 \%)$, reversing it in $3(30 \%)$ and dismissing the request in 1 case $(10 \%)$.

The only case allowing access to information on public interest grounds was case no. AI1627. ${ }^{57}$ Here, the Bank initially denied access to a request for an unpublished report on the basis that it was covered by one of the ten exceptions, as part of deliberative information. The applicant challenged the denial before the AI Committee, stating that the information was being sought for ongoing empirical research, and that it may have contained data which was usually hard to find. The AI Committee decided to release the report as it found the reasons set forth in the application to be compelling.

In two other cases, AI0773 ${ }^{58}$ and AI $3892,{ }^{59}$ the AI Committee decided to exercise the Bank's prerogative to disclose restricted information. This pre-

54 See World Bank, 'AIC Decisions on Appeals', available at http://www.worldbank.o $\mathrm{rg} / \mathrm{en} /$ access-to-information/aicdecisions (last visited 21 November 2018).

55 Appeals must be filed within 60 calendar days of the Bank's initial decision to deny access. World Bank, supra note 19, Section III, 8., (b), i., 18.

56 See World Bank, 'AIAB Decisions on Appeals', available at http://www.worldbank.org/en/access-to-information/aiabdecisions (last visited 21 November 2018).

57 AI Committee, 'Cost Recovery Report Regarding Sanitation in India Case no. AI1627’ (30 May 2012), available at http://pubdocs.worldbank.org/en/8299214338 85011761/18-AIC-appeal-18-Case-AI1627.pdf_(last visited 6 December 2018).

58 AI Committee, 'The Imataca Forest Reserve and Environs: Issues in Resource Planning, Public Participation and Sustainable Management, August 1999, Case no. AI0773' (13 July 2011), available at http://pubdocs.worldbank.org/en/5579214 33884471821/8-AIC-appeal-8-Case-AI0773.pdf (last visited 6 December 2018) [AI Committee, Imataca Forest Reserve and Environs].

59 AI Committee, 'World Bank Group Procedure on Country Engagement, Case no. AI3892' (23 February 2016), available at 
rogative allows for documents falling into one of the three exceptions potentially covered by public interest override (i.e. corporate administrative matter, deliberative information and financial information) to be disclosed, under exceptional circumstances, if the Bank determines that the overall benefits of such disclosure outweigh the potential harm to the interest $(s)$ protected by the exception $(s) .{ }^{60}$

In both of these cases, the AI Committee was not convinced by the arguments of the appellant to enable a public interest override. Requesting the release of an unpublished report on a Venezuelan rain forest in case AI0773, the appellant argued that:

[T] he public interest relates to the nature of this report. The document comprises of analysis based on information that is not readily available pertaining to an important biologically diverse environment situated near a UN designated World Heritage site. There is clear public interest in learning about the World Bank's findings and analyses on South America's ecologically vulnerable rain forests. ${ }^{61}$

The appellant in case AI3892 developed a more elaborate argument in favour of a public interest override. Requesting the release of the World Bank Group Procedure on Country Engagement, the appellant referred to decision AI1627 mentioned above and stated that:

$[\mathrm{T}]$ here is a public interest case for publishing the Bank's Procedures in general and the requested Procedure in particular. Procedures, including the requested one, are relevant for scientific research on international law and global governance. ${ }^{62}$

However, the AI Committee found no compelling public interest reason to override the exception in both cases. In case AI3892, the AI Committee explained its decision by the fact that the request was different than the one in case AI1627 as "the information requested was of a distinct nature and of a different subject matter; a knowledge report with data on sanitation services in India as opposed to a document with internal work processes." 63

http://pubdocs.worldbank.org/en/992431463172426839/41-AIC-Decision-Case-Nu mber-AI3892-A-final-for-website.pdf (last visited 6 December 2018) [AI Committee, World Bank Group Procedure on Country Engagement].

60 World Bank, supra note 19, Section IV, 1., 19.

61 AI Committee, supra note 58, 1, 2, para. 3.

62 AI Committee, supra note 59, 2, para. 4.

63 Ibid., 5, para. 13. 
The documents were nevertheless disclosed as the test of potential harm was conclusive in both cases.

The test of potential harm was also applied in other cases, but with different results. In case IA235964, for example, the test of potential harm gave rise to quite a unique situation in which only a portion of the requested information was released, specifically the name of the winning bidder and the contract value. ${ }^{65}$ Finally, in case IA2732, ${ }^{66}$ the appellant requested the release of a document commissioned by the Bank on the impact of hydropower projects on Ganga River asserting that this document "is unscientific and weak and, for this reason, [the Bank needs to release it] so that the people can get an alternative view of the cumulative impact of these projects" ${ }^{67}$ After consulting with relevant business units, the AI Committee came to the conclusion that the test of potential harm was inconclusive, and thus did not disclose the document.

This cluster of decisions shows that the AI Committee has adopted a very restrictive definition of public interest throughout its first eight years. It is this restrictive definition which has led to only one decision in favour of a public interest override. Whilst it is true that most of the other decisions on public interest override were turned out based on reasons that leave little space for the invocation of a public interest, ${ }^{68}$ another path could have been taken by the AI Committee for at least the four abovementioned cases on the exercise of the Bank's prerogative.

These decisions also show that the AI Committee is carefully analysing the arguments advanced by the appellants. In cases where the requester provided no reason in support of the public interest appeal, the AI Com-

64 AI Committee, 'Certain Corporate Procurement Information Concerning the Consulting Project (Selection \#1061565, “BEEPS v. Turkey”), Case no. AI2359’ (19 June 2013), available at http://pubdocs.worldbank.org/en/560351433946961433/2 1-AppealsDecisionCaseNumberAI2359A.pdf (last visited 6 December 2018) [AI Committee, BEEPS v. Turkey].

65 Ibid., 4, para. 8.

66 AI Committee, 'Study Done by Mott MacDonald on Cumulative Impacts of Hydropower Projects on Ganga River, Case no. IA2732', (24 June 2013), available at http://pubdocs.worldbank.org/en/929061433948885353/25-AIC-appeal-25-Case-AI 2732.pdf (last visited 6 December 2018).

67 Ibid., 2, para. 2.

68 It includes inter alia the fact that the requested document is not existing, or already public (cases IA0199, IA0495, IA 3157, IA3127), that the document was covered by an exception that the AI Committee has no authority to override (cases IA0262, IA0287, IA2605, IA4191), or that access was already granted on the basis of a violation prima facie of the policy (cases IA1437, IA4148). 
mittee simply dismissed the public interest portion of the appeal. ${ }^{69}$ In cases where reasons were provided, the AI Committee was, however, reluctant to recognise a public interest in releasing documents relating to internal processes, even for its own internal work processes. ${ }^{70}$

It may also be noted that, overall, a surprisingly small number of cases were brought before the AI Appeals Board. ${ }^{71}$ In annual surveys conducted by the Bank, ${ }^{72}$ it appears that the main reasons for respondents not filing a second stage appeal were a general lack of confidence in the system, a lack of knowledge of the AI Appeals Board, and the perception that an appeal would take too much time or is too complex.

\section{The Nature of the AI Procedure: a Quasi-Judicial Appeals Process}

While it is clear that the AI Procedure is not composed of actual courts or tribunals, it is a plausible option to place its organs in the category of quasi-judicial bodies. In the recent past, the notion of quasi-judicial body was often used in order to describe a large and diverse array of international organs. ${ }^{73}$ Among them, for instance, are the United Nations Human Rights Committee, ${ }^{74}$ the Committee against Torture, ${ }^{75}$ and even the WTO

69 See cases no. IA0708 and IA1170.

70 See case no. IA0294 requesting the release of attachments to the Access to Information Staff Handbook.

71 The fact that no appeal was introduced in the first 18-month period following the creation of the AI Appeals Board was already a preoccupation for the World Bank. See World Bank, 'World Bank Policy on Access to Information - Experience in the First 18 Months of Implementation' (19 December 2012), available at http://d ocuments.worldbank.org/curated/en/882191468325173418/pdf/NonAsciiFileNam e0.pdf (last visited 6 December 2018), 8, para. 23.

72 World Bank, 'Access to Information Surveys', available at http://www.worldbank.org/en/access-to-information/reports (last visited 6 December 2018).

73 See M. Tignino, Quasi-judicial bodies, in C. Brölmann \& Y. Radi, Research Handbook on the Theory and Practice of International Law making (2016), 242-261.

74 See for example T. Burgenthal, The U.N. Human Rights Committee, in J. A. Frowein \& R. Wolfrum (eds.), 5 Max Planck Yearbook of United Nations Law (2001), 395-396.

75 A. Constantinides, Transjudicial Dialogue and Consistency in Human Rights Jurisprudence: A Case Study on Diplomatic Assurances against Torture, in O. K. Fauchald \& A. Nollkaemper (eds.), The Practice of International and National Courts and the (De-) Fragmentation of International Law (2012), 269. 
Panels. ${ }^{76}$ If picking examples of quasi-judicial bodies can be simple for well-informed legal researchers, defining in legal terms what they are is more complicated than may appear at first glance. One of the few definitions of the notion of quasi-judicial body even starts with: "quasi-judicial is a term that is $[\ldots]$ not easily definable." ${ }^{77}$

The first move of any definitional attempt is indeed to delineate the field to be studied. The category of quasi-judicial bodies can be logically described as composed of organs that cannot be qualified either as judicial or as non-judicial, and which are somehow in between these two poles. The test of "quasi-judiciality" would then be defined as being essentially a failure of the test of judiciality.

Identifying a "test of judiciality" may be simple, given that much of the literature on international adjudication starts by defining judicial bodies at the international level. In order to be identified as an international judicial body, five criteria are usually evident: 1 ) it must be a permanent institution, ${ }^{78}$ 2) composed of international judges ${ }^{79}$ or, more generally, of independent persons vested with adjudicatory functions, ${ }^{80} 3$ ) adjudicating disputes between two or more entities, at least one of which is either a state or an international organization, ${ }^{81} 4$ ) which is working on the basis of predetermined rules of procedure, ${ }^{82}$ and 5 ) renders legally binding decisions based on law. ${ }^{83}$ If an international body were to "fall short on one or more of [these] five criteria", ${ }^{84}$ then it may be considered as a quasi-judicial or a non-judicial one.

76 V. Hugues, The Institutional Dimension, in D. L. Bethlehem et al. (eds.), The Oxford Handbook of International Trade Law (2009), 277.

77 G. W. Paton, A Textbook of Jurisprudence (1972), 336.

78 See C. P. R. Romano, The Proliferation of International Judicial Bodies: The Pieces of the Puzzle, 31 NYU Journal of International Law and Politics (1999), 711-723; J. E. Alvarez, International Organizations as Law-Makers (2006), 458.

79 Ibid.

80 See C. Tomuschat, International Courts and Tribunals with Regionally Restricted and/or Specialized Jurisdiction, in Judicial Settlement of International Disputes: International Court of Justice, Other Courts and Tribunals, Arbitration and Conciliation (1987), 290-312.

81 Romano, supra note 78, 711-723; Alvarez, supra note 78, 458.

82 Ibid.

83 See S. Rials, Ouverture: l'office du juge, in La fonction de juger, Droits, (1989), no. 9, 7. H. Ruiz Fabri, Le réglement des différends au sein de l'OMC: naissance d'une juridiction, consolidation d'un droit, in Souveraineté étatique et marchés internationaux à la fin du 20ème siècle. A propos de 30 ans de recherche du CREDIMI - Mélanges en l'honneur de Philippe Kahn (2000), 309.

84 Alvarez, supra note 78, 459. 
Such a residual definition of an international quasi-judicial body remains however relatively large in scope, and leaves several questions unanswered: is a body which fulfils only one of two of these criteria a quasi-judicial body or something else? Do these criteria have an identical weight in the context of this test? Some authors have adopted quite a broad definition of quasi-judicial procedures, as:

Procedures whose rulings are either legally binding or non-binding, and which are more or less destined for the settlement of differences between the parties by judge-like persons through, to some extent, legal process. ${ }^{85}$

One might adopt a restrictive approach and interpret each of these criteria in a strict manner. The limit between judicial bodies and "the others" is however not as rigid as it may seem to be. The dividing lines between international judicial bodies and other adjudicative bodies, such as arbitral tribunals, are somewhat vague. Cesare Romano, Karen Alter and Yuval Shany have identified for example, two modes of adjudication by somehow expanding the definition of international courts and tribunals:

[B]y way of judicial bodies and by way of arbitration. Judicial bodies pre-exist the question that is to be decided. [...] Conversely, in arbitration, the adjudicators are selected by the parties after the dispute arises, with the aim of deciding a particular case. ${ }^{86}$

Accordingly, international adjudicative bodies are different from "diplomatic means and even political decision-making and quasi-judicial bodies" ${ }^{87}$ The practice, however, shows that organs that are neither international courts, nor arbitral tribunals, are sometimes performing adjudicative tasks.

At the other end of the spectrum are non-judicial bodies performing a dispute settlement task. Legal scholars usually see the criteria of judiciality as being the end of a process - an ideal situation to achieve - especially when it comes to independence and impartiality. José Alvarez notes, for example, that:

85 Y. Shigeta, International Judicial Control of Environmental Protection: Standard Setting, Compliance Control and the Development of International Environmental Law by the International Judiciary (2010), 188.

86 C. P. R. Romano et al., Mapping International Adjudicative Bodies, the Issues and Players, in C. P. R. Romano et al. (eds.), The Oxford Handbook of International Adjudication (2013), 5.

87 Ibid., 6. 
These other quasi-judicial dispute settlers are generally distinguishable from [non-judicial actors] because they are all characterized by some serious attempt, primarily through rules for the type of expertise required of the dispute settlers, their method of selection, or their tenure in office (or all three), to recognize the 'independent' status of the third party decision-maker from the governments involved in their creation. ${ }^{88}$

In the context of the AI Procedure, it is clear that neither the AI Committee, nor the AI Appeals Board, can be seen as courts according to the criteria mentioned above. It also appears more appropriate to treat the AI Committee and the AI Appeals Board separately. Having a procedure composed of two organs of a different nature is indeed a possibility. As noted by Megan Donaldson and Benedict Kingsbury, the "first-tier review mechanisms resemble administrative review mechanisms within public authorities, and the second-tier review, where it exists, is often clothed in the language of judicial and quasi-judicial process" ${ }^{99}$ Treating both organs as quasi-judicial has also been proposed by other authors. ${ }^{90}$ Be that as it may, the AI Committee is clearly carrying out a dispute settlement function; the same function carried out by the AI Appeals Board, and is thus not a nonjudicial organ.

Furthermore, differentiating a quasi-judicial nature from an administrative one can be a tricky exercise, especially outside of a domestic setting. Based on a common law version of these two notions, one could indeed argue that the AI Committee is an administrative organ, as it carries out an internal function based on policies of the Bank, while the AI Appeals Board is a quasi-judicial organ, as it carries out its function in an independent manner and as it were, in some respects, a judicial function.

It appears that quasi-judiciality is not a "one size fits all" concept. The reality of today's dispute settlement mechanisms of international organisations may be far more complex than it appears. The time has come to take

88 Alvarez, supra note $78,459$.

89 M. Donaldson \& B. Kingsbury, Power and the Public: The Nature and Effects of Formal Transparency Policies in Global Governance Institutions, in A. Bianchi \& A. Peters (eds.), Transparency in International Law (2013), 516. See also Fujita, supra note $53,17$.

90 G. L. Burci, Inviolability of Archives (Article III Section 6 Specialized Agencies Convention), in A. Reinisch (ed.), The Convention on the Privileges and Immunities of the United Nations and its Specialized Agencies - A Commentary (2016), 187. 
a closer look at these clusters of quasi-judicial organs, with the aim in fine to propose a more precise taxonomy of international quasi-judicial bodies.

\section{Concluding Remarks: Procedural Innovation, the World Bank, and the Others}

Albeit that establishing a review process for decisions denying access to information is not per se an innovation, the World Bank AI Procedure is striking for its novelty. The World Bank was the first of the international financial institutions to establish a two-stage appeals process with one stage being conducted by an external independent body. Other international financial institutions subsequently revised their own policies to include such a procedure. The Inter-American Development Bank revised its policy in May 2010 to include a three-member external panel to hear appeals at its second stage. ${ }^{91}$ The Asian Development Bank (ADB) also revised its policy in 2011 to create the Independent Appeals Panel (IAP) composed of three transparency experts. ${ }^{92}$ Similarly, in 2012 the African Development Bank (AfDB) established an Appeals Panel composed of three members, with two of the members external to the Bank..$^{93}$ This phenomenon of "cross-institutional normativity" 94 initiated by the World Bank has been interpreted by some authors as announcing the progressive emergence of a droit commun of international financial institutions..$^{95}$

91 See Inter-American Development Bank, 'Access to Information Policy', available at http://idbdocs.iadb.org/wsdocs/getdocument.aspx?docnum=35167427 (last visited 6 December 2018).

92 ADB, 'New Independent Appeals Panel to Strengthen ADB's Transparency' (25 June 2012), available at http://www.adb.org/news/new-independent-appeals-panel -strengthen-adbs-transparency (last visited 6 December 2018).

93 See AfDB, 'Appeals Process', available at http://www.afdb.org/en/disclosure-and-access-to-information/appeals-process/ (last visited 6 December 2018).

94 B. Kingsbury, Global Administrative Law in the Institutional Practice of Global Regulatory Governance, in H. Cissé et al. (eds.), The World Bank Legal Review Volume 3: International Financial Institutions and Global Legal Governance (2012), 20.

95 L. Boisson de Chazournes, Partnerships, Emulation, and Coordination: Toward the Emergence of a Droit Commun in the Field of Development Finance, in H. Cissé et al. (eds.), The World Bank Legal Review Volume 3: International Financial Institutions and Global Legal Governance (2012), 173-187. 
This droit commun of access to information does not, however, provide full transparency of the activities of international financial institutions. The reluctance of these institutions to allow their independent body's full rein in the assessment of public interest overrides can be interpreted as a means of retaining control over the information to be shared. The World Bank, as any other public institution, must reach a balance between transparency and confidentiality. Whilst transparency is necessary in order to enhance legitimacy, keeping some information confidential is vital for some of the Bank's core missions. The next step for the Bank, and the other international financial institutions, may be to go beyond the presumption that independence means lack of control, and trust their independent bodies to carry out their task, including when it comes to evaluating a public interest to disclose, in a responsible manner. 
